\title{
Therapeutic implications of tumor free margins in head and neck squamous cell carcinoma
}

\author{
Clara Backes $^{1}$, Henning Bier ${ }^{1}$ and Andreas Knopf ${ }^{1}$ \\ ${ }^{1}$ Otorhinolaryngology/Head and Neck Surgery, Klinikum rechts der Isar, Technische Universität München, 81675 München, \\ Germany \\ Correspondence to: Andreas Knopf, email: knopf.ent@gmail.com \\ Keywords: RO, tumor free margin, head and neck, adjuvant therapy, surgery \\ Received: June 10,2017 Accepted: August 05, $2017 \quad$ Published: September 16, 2017 \\ Copyright: Backes et al. This is an open-access article distributed under the terms of the Creative Commons Attribution License \\ 3.0 (CC BY 3.0), which permits unrestricted use, distribution, and reproduction in any medium, provided the original author and \\ source are credited.
}

\section{ABSTRACT}

Objectives: The resection status is one of the most important prognostic factors for patients with head and neck squamous cell carcinoma (HNSCC) concerning overall survival (OS) and recurrence free interval (RFI). To assess whether therapy concepts changed depending on different resection margins and extracapsular extension, OS and RFI data were set into clinical context.

Methods: All HNSCC patients who underwent head and neck surgery with/without adjuvant therapy $(n=534)$ were selected over a ten-year period (2001-2011). Clinical parameters and survival data were collected retrospectively and histopathological analysis of tumor free margins and extracapsular extension were done.

Results: Patients with microscopic in-sano resection showed mean OS/RFI of 95/96 months. OS/RFI decreased in microscopic non-in-sano and macroscopic nonin-sano (56/58 and 35/39 months) as well as in unclear resection margins (63/60 months). Patients with extracapsular extension, microscopic non-in-sano resection as well as patients with in-sano resection after follow up resection demonstrated therapy escalation by adjuvant (chemo-) radiation.

Conclusions: Insufficient surgical margins and extracapsular extension are main risks for a reduced overall and recurrence free survival. Although there is no measure to prevent positive extracapsular extension, clear margins at first pass protect patients from adjuvant therapy escalation.

\section{INTRODUCTION}

Head and neck cancers (HNC) constitute the sixth cause of cancer-related deaths worldwide [1]. In fact, most recent epidemiological data estimates 686,000 new cases and 376,000 deaths in 2012 [2]. HNC are regarded not as a single entity but rather as a heterogeneous group of tumor types with the majority of them (90\%) corresponding to squamous cell carcinoma (HNSCC). While HNSCC rate decreased, particularly the rate of laryngeal cancer, the rate of oropharyngeal (HPV-related) cancer increased [3]. Changing trends in the incidence of different HNSCC subtypes with a simultaneous decline in tobacco-associated and increase in human papillomavirus
(HPV)-mediated carcinomas result in improvement in 5-year overall survival [4]. A multimodal treatment, consisting of surgery, radiation and chemotherapy, has proved to be successful for most cases [5]. However, there are still controversies when establishing specific guidelines for treatment options [5]. Surgical resection, usually gold standard for treating patients with HNSCC, aims to completely resect the tumor and simultaneously preserve the organ, this way keeping the individuals' quality of life and improving the overall survival rate (OS) at the same time [6]. Each treatment is done according to different factors, including tumor location, staging, the presence of a positive margin, extracapsular extension (ECE) status and the general health issues of the patient 
$[7,8]$. Nevertheless, cured patients may suffer side effects of aggressive procedures and often, these tumors relapse $[9,10]$.

One of the main risks for local recurrence represents positive resection margin [11]. Unfortunately, there is not yet consensus in the definition of margins size that could be used in a straightforward manner for treatment decisions [12]. This poses a serious problem as imprecise tumor edges may lead to a second resection if the surrounding tissue is not histopathologically tumor-free [10]. Furthermore, ECE status represents another prognostic factor for OS and RFI. Both, positive margin and ECE positivity are standard indications for adjuvant chemoradiotherapy (CRT) [13-15]. However, based on the difficulty to clarify these risk factors and to optimize therapies, the analysis of cases where CRT means overtreatment, still needs to be addressed. The adequate implementation of adjuvant therapies shows high importance due to its impact on long term morbidities for the patients. Late toxicity effects, such as sicca syndrome, dysphagia and pneumonia were already reported in other studies [16, 17].

The current study investigates OS and recurrencefree interval (RFI) in 534 patients, depending different $\mathrm{R}$ status (R0 at first pass, R0 by follow up resection, R1, $\mathrm{R} 2$, and $\mathrm{Rx}$ ) and distinguishes CRT therapy escalation by positive ECE status or insufficient tumor free margins.

\section{RESULTS}

\section{Clinico-pathological characteristics}

A total of 534 patients were analysed for disease related data comprising 341 patients who underwent $\mathrm{R} 0$ resection at first pass, 55 patients with R0 status by follow up resection, 77 patients with R1 resection, seven patients with R2 resection, and 54 patients with Rx status, respectively (Table 1). Mean patient's age ranged from 55 to 63 years without differences between the groups $(\mathrm{p}=0.9$; Table 1). Differential analysis of patient's gender demonstrated significant differences between the groups $(\mathrm{p}=0.009$; Table 1). Post-hoc analysis attributed differences between the groups to a higher percentage of women in R2 resection, while no differences could be observed between other groups. Analysis of location at primary tumor site revealed oropharyngeal carcinoma being the most frequent primary tumor site. There were striking differences between the distributions of tumor localization with respect to different R-status that refer to an increased proportion of sinonasal and oropharyngeal carcinoma after $\mathrm{Rx}$ resection $(\mathrm{p}<0.0001$; Table 1). Interestingly, subgroup analysis of $\mathrm{T}$ status failed to achieve differences between the groups ( $p=0.13$; Table 1). While in a substantial proportion of our patients higher $\mathrm{T}$ status rather depends on functional aspects and tumor compartmentation than metric parameter (e.g. maximum tumor diameter) at primary tumor site, analysis of maximum tumor diameter and tumor free margins were performed. Maximum tumor diameter ranged from 24 to $25 \mathrm{~mm}$ without differences between the groups $(\mathrm{p}=0.94$, Table 2). The minimum tumor free margin was $4 \mathrm{~mm}$ in $\mathrm{R} 0$ resection at first pass and $5 \mathrm{~mm}$ after follow up resection $(p=0.053$; Table 2$)$. While the vast majority of patients with $\mathrm{R} 0$ resection at first pass or after follow up resection showed circumferential margins being the smallest, patients with R1 resection showed a significant increase in small deep margins after post-hoc analysis $(p=0.41$; Table 2). Significant differences in $N$ status between the groups referred to increased $\mathrm{pN} 2 \mathrm{~b} / \mathrm{N} 3$ status after $\mathrm{R} 2$ resection ( $\mathrm{p}$ $=0.042$; Table 1$)$. The vast majority of patients showed M0 status at the time of diagnosis $(\mathrm{p}=0.88$; Table 1$)$. Analysis of primary tumor grading demonstrated G2/3 differentiated carcinoma in all groups $(\mathrm{p}=0.15$; Table 1$)$.

\section{Resection status determines survival and tumor recurrence}

Analysis of overall (OS) and recurrence free survival (RFI) revealed significant differences between the groups. While patients with R0 resection showed mean OS of 95 months, OS decreased to 56 months after $\mathrm{R} 1$ resection and 35 months after R2 resection. Patients who underwent Rx resection showed OS of 63 months $(p<0.0001$; Figure 1a). Concordant with results of OS, patients with R0 resection showed prolonged RFI of 96 months when compared with patients after R1 resection (58 months), and $\mathrm{R} 2$ resection (39 months), respectively. RFI in patients with Rx resection was 60 months ( $<<$ 0.0001; Figure 1b). Forward selected, proportional Cox regression of survival modifying parameters $(\mathrm{T}$, gender, surgical procedure, and localization of primary tumor) identified increasing $\mathrm{T}$ status being the only OS-modifying parameter in $\mathrm{HNSCC}(\mathrm{T} 1 / 2$ vs. $\mathrm{T} 3 / 4: \mathrm{HR}=1.6[95 \% \mathrm{CI}=$ $1.1-2.3], \mathrm{p}=0.012)$. No differences could be demonstrated with respect to RFI. Subgroup analysis was performed in patients with $\mathrm{R} 0$ resection at first pass and after follow up resection (Figure 1c and 1d). Both, OS and RFI were comparable in patients who underwent $\mathrm{R} 0$ resection at first pass and by follow up resection $(p=0.94$; Figure $1 c ; p$ $=0.36$; Figure 1d). Forward selected, proportional Cox regression of OS/RFI modifying parameters ( $\mathrm{T}$, gender, surgical procedure, and localization of primary tumor) did not reveal differences between the subgroups.

\section{Insufficient resection status enforces adjuvant therapy escalation}

OS and RFI data were set into clinical context in order to estimate whether treatment regimens changed with respect to different R status. Analysis of surgical approaches showed no differences between surgical concepts at primary tumor site $(\mathrm{p}=0.16)$, while 
Table 1: Clinical and histological parameter of the analyzed cohort

\begin{tabular}{|c|c|c|c|c|c|c|}
\hline & R0 FP & R0 FUR & R1 & $\mathbf{R 2}$ & $\mathbf{R x}$ & p-value \\
\hline $\mathbf{n}$ & 341 & 55 & 77 & 7 & 54 & \\
\hline Age (years) & & & & & & 0.9 \\
\hline Median & 59 & 55 & 56 & 63 & 58 & \\
\hline Mean \pm SD & $59 \pm 10$ & $58 \pm 10$ & $59 \pm 10$ & $61 \pm 12$ & $59 \pm 10$ & \\
\hline Sex, n (\%) & & & & & & 0.009 \\
\hline Male & $310(91)$ & $46(84)$ & $60(78)$ & $6(86)$ & $43(80)$ & \\
\hline Female & $31(9)$ & $9(16)$ & $17(22)$ & $1(14)$ & $11(20)$ & \\
\hline Location, n (\%) & & & & & & $<0.0001$ \\
\hline Sinonasal system & $11(3)$ & $4(7)$ & $2(3)$ & 0 & $11(20)$ & \\
\hline Nasopharynx & 0 & 0 & $2(3)$ & 0 & 0 & \\
\hline Oropharynx & $129(38)$ & $17(31)$ & $33(43)$ & $2(29)$ & $27(50)$ & \\
\hline Hypopharynx & 49 (14) & $8(15)$ & $16(21)$ & $2(29)$ & $6(11)$ & \\
\hline Larynx & $72(21)$ & $13(24)$ & $15(20)$ & $1(14)$ & $9(17)$ & \\
\hline Oral cavity & $80(24)$ & $13(24)$ & $9(12)$ & $2(29)$ & $1(2)$ & \\
\hline T stage, n (\%) & & & & & & 0.13 \\
\hline $\mathrm{T} 1$ & $139(41)$ & $21(38)$ & $30(39)$ & $1(14)$ & $16(30)$ & \\
\hline $\mathrm{T} 2$ & $124(36)$ & $19(35)$ & $30(39)$ & $1(14)$ & $25(46)$ & \\
\hline $\mathrm{T} 3$ & $41(12)$ & $13(24)$ & $6(8)$ & $3(43)$ & $7(13)$ & \\
\hline $\mathrm{T} 4$ & $37(11)$ & $2(4)$ & $11(14)$ & $2(29)$ & $6(11)$ & \\
\hline N stage, n (\%) & & & & & & 0.042 \\
\hline N0 & $171(50)$ & $30(55)$ & $38(49)$ & $1(14)$ & $24(44)$ & \\
\hline N1 & $59(17)$ & $7(13)$ & $2(3)$ & $1(14)$ & $7(13)$ & \\
\hline $\mathrm{N} 2 \mathrm{a}$ & $83(24)$ & $12(22)$ & $30(39)$ & $3(43)$ & $15(28)$ & \\
\hline $\mathrm{N} 2 \mathrm{~b}$ & $26(8)$ & $6(11)$ & $6(8)$ & $1(14)$ & $7(13)$ & \\
\hline N3 & $2(1)$ & 0 & $1(1)$ & $1(14)$ & $1(2)$ & \\
\hline \multicolumn{7}{|l|}{ M stage, n (\%) } \\
\hline M0 & 338 (99) & $55(100)$ & $76(99)$ & $7(100)$ & $53(98)$ & 0.88 \\
\hline M1 & $3(1)$ & 0 & $1(1)$ & 0 & $1(2)$ & \\
\hline \multicolumn{7}{|l|}{ Grading, n (\%) } \\
\hline G1 & $14(5)$ & $2(4)$ & $1(1)$ & 0 & $1(2)$ & 0.15 \\
\hline G2 & $184(54)$ & $28(51)$ & $28(36)$ & $5(71)$ & $23(43)$ & \\
\hline G3 & $135(40)$ & $23(42)$ & $47(61)$ & $2(29)$ & $30(55)$ & \\
\hline G4 & $3(1)$ & $1(2)$ & 0 & 0 & 0 & \\
\hline Gx & $3(1)$ & $1(2)$ & $1(1)$ & 0 & 0 & \\
\hline
\end{tabular}


Table 2: Histological metric data of primary tumor and tumor free margin

\begin{tabular}{|c|c|c|c|c|}
\hline & R0 FP & R0 FUR & R1 & p-value \\
\hline $\mathbf{n}$ & 341 & 55 & 77 & \\
\hline Largest primary tumor's diameter [mm] & $24 \pm 13$ & $25 \pm 13$ & $24 \pm 15$ & 0.94 \\
\hline Minimum tumor free margin [mm] & $4 \pm 4$ & $5 \pm 5$ & & 0.053 \\
\hline Smallest tumor free margin & & & & 0.41 \\
\hline Circumference & $160(47)$ & $28(51)$ & $27(35)$ & \\
\hline Deep margin & $129(38)$ & $17(31)$ & $35(46)$ & \\
\hline Both & $52(15)$ & $9(16)$ & 15 (19) & \\
\hline
\end{tabular}

significant differences were demonstrated in the extent of neck dissection $(p=0.007$; Table 3$)$. However, post-hoc analysis attributed differences between the groups to a discrepancy of R0 resection at first pass and R1 resection. There were no differences between the other groups. Positive ECE status, being the most important indicator to recommend adjuvant CRT, was demonstrated in $9 \%$ of patients after R0 resection at first pass, in 7\% of R0 resection by follow up resection, in 9\% after R1 resection, 14\% after R2 resection, and 15\% after $\mathrm{Rx}$ resection, respectively $(\mathrm{p}=0.61$; Table 3$)$. In contrast, adjuvant CRT was applied in $24 \%$ and $25 \%$
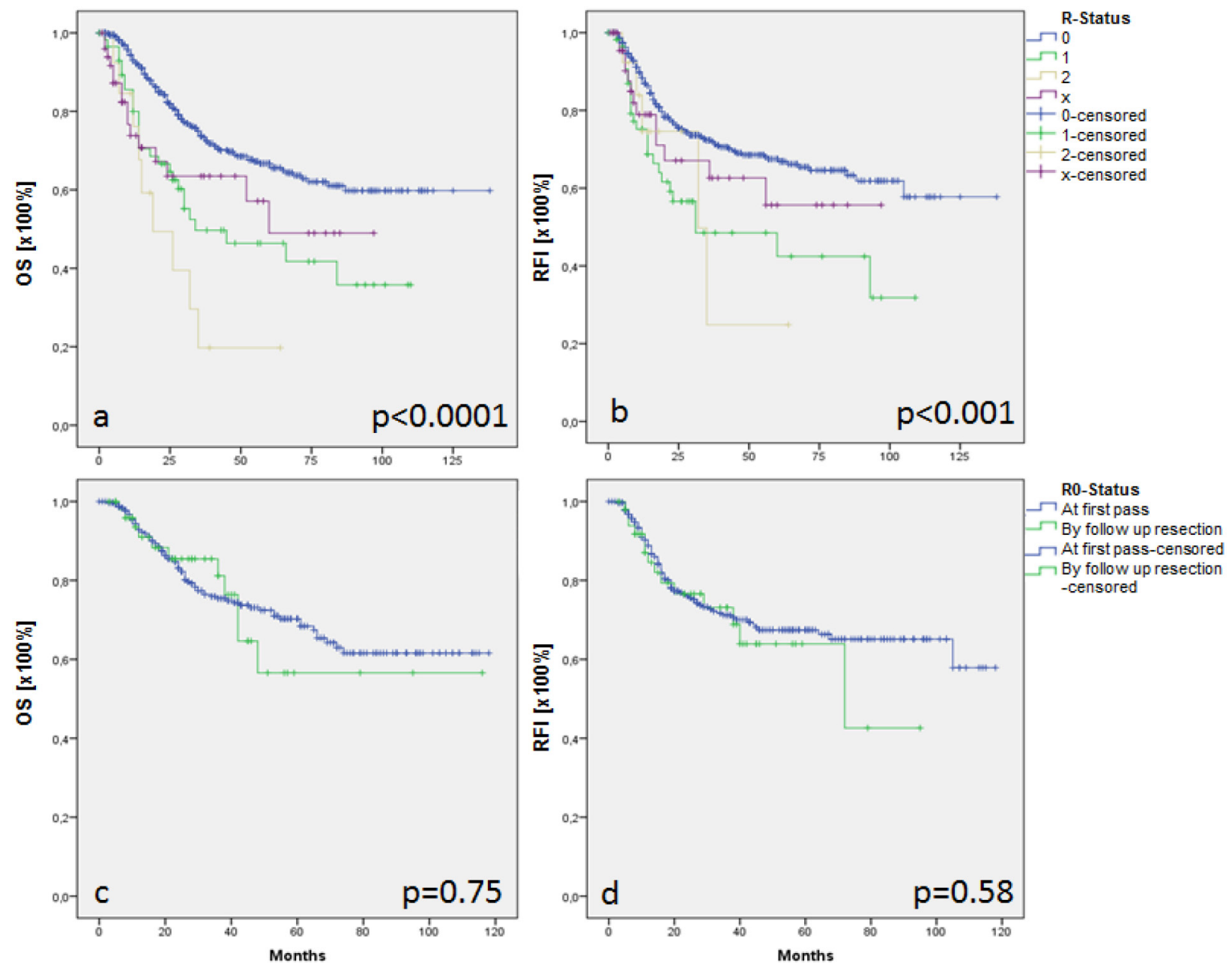

Figure 1: Overall survival (OS) and recurrence free interval (RFI) in patients with R0 resection (a, b, blue line), R1 resection (a, b, green line), $\mathrm{R} 2$ resection ( $\mathrm{a}, \mathrm{b}$, yellow line) and Rx resection ( $\mathrm{a}, \mathrm{b}$, purple line). Subgroup analysis of OS and RFI after R0 resection by first pass (c, d, blue line) or follow up resection (c, d, green line). 
Table 3: Therapeutic regimen

\begin{tabular}{|c|c|c|c|c|c|c|}
\hline & R0 FP & R0 FUR & R1 & $\mathbf{R 2}$ & $\mathbf{R x}$ & p-value \\
\hline $\mathbf{n}$ & 341 & 55 & 77 & 7 & 54 & \\
\hline Surgery at primary tumor site, n (\%) & & & & & & 0.16 \\
\hline Oral and oropharyngeal resection & $123(36)$ & $21(38)$ & $32(42)$ & $3(43)$ & $13(24)$ & \\
\hline Transmandibular resection & $37(11)$ & $4(7)$ & $9(12)$ & 0 & $4(7)$ & \\
\hline Pharyngotomy & $28(8)$ & $1(2)$ & 0 & 0 & $4(7)$ & \\
\hline Vertical partial laryngectomy & $3(1)$ & $2(4)$ & $4(5)$ & $2(29)$ & 0 & \\
\hline Horizontal partial laryngectomy & $3(1)$ & $1(2)$ & $1(1)$ & 0 & 0 & \\
\hline Transoral laser partial laryngectomy & $55(16)$ & $13(24)$ & $14(18)$ & $2(29)$ & $14(26)$ & \\
\hline Pharyngo-/Laryngectomy & $57(17)$ & $7(13)$ & $11(14)$ & 0 & $3(6)$ & \\
\hline Transfacial resection & $11(3)$ & $4(7)$ & $3(4)$ & 0 & $11(15)$ & \\
\hline Other technique & $7(2)$ & $1(2)$ & $1(1)$ & 0 & $4(7)$ & \\
\hline Partial mandibulectomy & $17(5)$ & $1(2)$ & $2(3)$ & 0 & $1(2)$ & \\
\hline Neck dissection, n (\%) & & $1(2)$ & & & & 0.007 \\
\hline None & $59(17)$ & $20(37)$ & $22(29)$ & $1(14)$ & $13(24)$ & \\
\hline Ipsi-lateral & $105(31)$ & $29(54)$ & $34(40)$ & $4(57)$ & $19(35)$ & \\
\hline Bilateral & $177(52)$ & $6(11)$ & $21(27)$ & $2(14)$ & $22(41)$ & \\
\hline ECE status, n (\%) & & & & & & 0.61 \\
\hline Negative & $309(91)$ & $51(93)$ & $70(91)$ & $6(86)$ & $46(85)$ & \\
\hline Positive & $32(9)$ & $4(7)$ & $7(9)$ & $1(14)$ & $8(15)$ & \\
\hline Adjuvant therapy, n (\%) & & & & & & $<0.0001$ \\
\hline OP only & $105(31)$ & $21(38)$ & $15(20)$ & 0 & $12(22)$ & \\
\hline $\mathrm{OP}+\mathrm{RT}$ & $154(45)$ & $20(36)$ & $24(31)$ & 0 & $17(32)$ & \\
\hline $\mathrm{OP}+\mathrm{CRT}$ & $82(24)$ & $14(25)$ & $38(49)$ & $7(100)$ & $25(46)$ & \\
\hline $\begin{array}{l}\text { Adjuvant therapy escalation by } \\
\text { insufficient R-status, n (\%) }\end{array}$ & & & & & & 0.002 \\
\hline None & $295(87)$ & $45(81)$ & $53(69)$ & 0 & $40(74)$ & \\
\hline RT & $11(3)$ & $3(6)$ & $3(4)$ & 0 & $3(6)$ & \\
\hline CRT & $35(7)$ & 7 (13) & $21(27)$ & $7(100)$ & $11(20)$ & \\
\hline
\end{tabular}

of patients after R0 resection (first pass and follow up resection), in $49 \%$ after $\mathrm{R} 1$ resection, $100 \%$ after R2 resection, and $46 \%$ after $\mathrm{Rx}$ resection, respectively ( $\mathrm{p}$ $<0.0001$; Table 3). Significant differences in adjuvant treatment concepts were further analysed to assess therapy escalation due to insufficient R status. Therapy escalation by RT/CRT was performed in $10 \%$ of patients with R0 resection at first pass due to small $(\leq$ $5 \mathrm{~mm}$ ) tumor free margins. RT/CRT therapy escalation demonstrated significant increase in patients with R0 status after follow up resection (19\%), R1 (31\%), and Rx status $(26 \%)(p=0.002$; Table 3$)$.

\section{DISCUSSION}

Advanced HNSCC still presents a 5-year rate of disease free survival of less than $50 \%$ [18]. Main reason is the difficulty of adequate tumor control when resection margin or ECE status is positive $[19,20]$. The current study investigated these factors and their impact on OS, RFI and CRT escalation in 534 patients between the years 2001 and 2011. There was a special focus on adjuvant therapeutic approaches after R0 resection at first pass and by follow up resection in order to set different $\mathrm{R}$ status into daily oncological context. 
In our series, there were no significant differences in gender and age within each respective $\mathrm{R}$ status ( $\mathrm{R} 0$ at first pass or by followed up resection, R1, R2 and Rx). However, post-hoc analysis constitutes a higher rate of female patients in $\mathrm{R} 2$ resection. Teutsch et al. demonstrated similar results, with more challenging surgical access to specific regions in the female cranio-cervical anatomy [21]. The distribution of tumor localization according to $\mathrm{R}$ status showed a disproportionately high percentage of sinonasal (20\%) and oropharyngeal (50\%) carcinomas with $\mathrm{Rx}$ resection. Limited possibility for en-bloc resection in these anatomically intricate regions could explain the $\mathrm{Rx}$ trends we observe in sinonasal neoplasms [22]. In these cases, a piecemeal surgical intervention is required [22]. The $\mathrm{Rx}$ status of oropharyngeal tumors undergoes similar classification. Although there is a variety of surgical methods to achieve a resection of these kind of malignancies, the accessibility to certain sites still needs to be improved [23]. No T status discrepancy classified by maximum tumor diameter was found between the subgroups. However, the post-hoc analysis of the smallest tumor free margin within each $\mathrm{R}$ status only revealed significance with $\mathrm{R} 1$ resection patients, where the amount of small deep margins increased.

Main focus of our study was to review OS and RFI of our patients depending on tumor's resection margin. As expected, patients with R0 resection showed the highest survival rate with a mean OS of 95 months. After R1 and $\mathrm{R} 2$ resection OS declined constantly to 56 and 35 months. Interestingly, patients with $\mathrm{Rx}$ resection attained a mean OS of 63 months. Comparable results were reported in earlier studies, although most of them concentrated on the exact margin size and its impact on recurrence and survival rate [24-27]. However, all of them showed the correlation between diminishing tumor free margins and shrinking OS. In accordance to the outcome of OS, patients with R0 resection demonstrated a RFI of 96 months, while $\mathrm{R} 1$ resection (58 months) and $\mathrm{R} 2$ resection (39 months) showed an impressive decrease. At the same time, Rx resection presented a RFI of 60 months. Eldeeb et al. described similar results in their investigation [26]. Their rate of local recurrence was particularly high, when clear surgical margins were less defined [26]. Adjuvant RT represents therapeutic mainstay in locally advanced tumors or even after insufficient R status to increase both, locoregional control and overall survival [28]. While conventional radiation (70-72 Gy over 7-7.5 weeks with 1.8-2.0 Gy daily) was the treatment of choice until late 1970 s, today's altered fractionation significantly increased locoregional control [28]. Since the earliest description by Bennett et al. in 1971 [29], a positive ECE, belongs to the main prognostic factors for OS and RFI. ECE is also most relevant for the indication of CRT [20, 30, 31]. However, a substantial proportion of HNSCC patients undergo adjuvant CRT due to insufficient $\mathrm{R}$ status. Concomitant platin-based adjuvant CRT improved outcome in patients with one or both of these risk factors [32]. Accordingly, in our series no differences in positive ECE status were found between the subgroups. Nonetheless, there were a significantly higher number of cases where adjuvant RT/ CRT was implemented than cases with positive ECE. Further investigation demonstrated a therapy escalation by aRT/aCRT in $10 \%$ of patients with $\mathrm{R} 0$ at first pass because of small tumor free margins. Additionally, the adjuvant treatment had a substantial significant increase for R0 after followed up resection (19\%), R1 (31\%) and $\mathrm{Rx}(20 \%)$. It is important to note that patients with R0 resection at first pass or after followed up resection had no significant difference in OS and RFI in our study. We have to assume that, particularly in the group of patients with R0 status by follow up resection, clear tumor free margins were jeopardized by challenging surgical access of cranio-cervical anatomy that impedes appropriate tissue correspondence. In this scenario, formally achieved $\mathrm{R} 0$ status by follow up resection rather refers to $\mathrm{Rx}$ or R1 status than R0 status at first pass. Therefore, adjuvant therapy escalation guaranteed survival rates comparable to patients who underwent $\mathrm{R} 0$ resection at first pass.

Recent literature estimates that unclear $\mathrm{R}$ status effected by the surgeon, leads to an unnecessarily high increase of morbidities for $18 \%$ of our patients [15]. The problem of late toxicity is described in earlier studies $[16,17,23]$. In 2012, Keereweer et al. [17] conducted a retrospective study for the morbidity factor in 73 patients after adjuvant treatment. Complications like dysphagia, pneumonia and dehydration were highlighted due to their negative influence on patients' quality of life [17]. Both, insufficient $\mathrm{R}$ status and positive ECE were described in the current study as high risk factors for OS and RFI. Although surgeons cannot influence the outcome of the extranodal extension, they can, through a well-defined cooperation with pathologists, achieve clear tumor free margins $[15,19,33]$. In HNSCC a consensus in definition of clear margins is still missing [19, 34, 35]. Furthermore, literature lacks information about the oncological outcome of patients with tumour free margins at first pass and after follow up resection. Recent meta-analysis in breast cancer indicates better locoregional control after $\mathrm{R} 0$ resection at first pass, without relationship between margin widths [36].

\section{CONCLUSION}

Tumor free margins at first pass reduce the necessity of adjuvant therapy escalation and, therefore, acute and late toxicity. Adjuvant therapy escalation in R0 status after follow up resection maintains recurrence-free and overall survival comparable to individuals with R0 status at first pass

\section{MATERIALS AND METHODS}

\section{Patient selection}

All patients who underwent head and neck surgery with/without adjuvant treatment $(n=534)$ in a period 
of ten years (2001-2011) were included in the current study. Diagnosis of mucosal head and neck squamous cell carcinoma was achieved after histological review by at least two experienced pathologists. Dysplasia, carcinoma in situ, and other histologic subtypes such as adenocarcinoma were excluded from the study. Clinical parameters (age, sex, TNM-staging referring to UICC $7^{\text {th }}$ edition, grading, and treatment modalities) and survival data (recurrence, and death/loss to follow-up) were retrospectively collected. The median and mean followup time were $24[11 ; 45]$ and 36 months.

\section{Analysis of tumor free margins and ECE status}

Histology was reviewed for maximum tumor diameter, circumferential and deep tumor free margins as well as tumor free margins at first pass or by follow up resection. Lymph node status was classified with respect to UICC $7^{\text {th }}$ edition classification system. ECE status was analysed for all tumor specimens.

\section{Statistical analysis}

Differences between the groups were analyzed using the Chi square test and Fisher exact test for categorical, and the unpaired student's t-test for continuous variables. ANOVA and Tukey's post-hoc was performed for analysis of more than two groups. Survival rates and curves were calculated and illustrated by the Kaplan-Meier method and further analyzed by the log-rank. Variables that revealed prognostic or effect modifying potential on the outcome were subsequently evaluated by the proportional Cox regression for forward selection. p-values $<0.05$ were considered statistically significant. Statistical analysis was done using SPSS (SPSS Inc., Chicago, IL).

\section{FINANCIAL DISCLOSURE}

All authors state no financial disclosures.

\section{CONFLICTS OF INTEREST}

All authors state no conflicts of interest.

\section{FUNDING}

Authors did not receive any funding associated with the study.

\section{REFERENCES}

1. Jemal A, Bray F, Center MM, Ferlay J, Ward E, Forman D. Global cancer statistics. CA Cancer J Clin. 2011; 61:69-90. https://doi.org/10.3322/caac.20107.
2. Ferlay J, Soerjomataram I, Dikshit R, Eser S, Mathers C, Rebelo M, Parkin DM, Forman D, Bray F. Cancer incidence and mortality worldwide: sources, methods and major patterns in GLOBOCAN 2012. Int J Cancer. 2015; 136:E359-86. https://doi.org/10.1002/ijc.29210.

3. Mourad M, Jetmore T, Jategaonkar AA, Moubayed S, Moshier E, Urken ML. Epidemiological trends of head and neck cancer in the United States: A SEER Population Study. J Oral Maxillofac Surg. 2017. https://doi.org/10.1016/j. joms.2017.05.008.

4. Mifsud M, Eskander A, Irish J, Gullane P, Gilbert R, Brown D, de Almeida JR, Urbach DR, Goldstein DP. Evolving trends in head and neck cancer epidemiology: Ontario, Canada 1993-2010. Head Neck. 2017; 39:1770-8. https:// doi.org/10.1002/hed.24829.

5. Marur S, Forastiere AA. Update on role of chemotherapy in head and neck squamous cell cancer. Indian J Surg Oncol. 2010; 1:85-95. https://doi.org/10.1007/s13193-010-0021-y.

6. Baddour HM Jr, Magliocca KR, Chen AY. The importance of margins in head and neck cancer. J Surg Oncol. 2016; 113:248-55. https://doi.org/10.1002/jso.24134.

7. Haque R, Contreras R, McNicoll MP, Eckberg EC, Petitti DB. Surgical margins and survival after head and neck cancer surgery. BMC Ear Nose Throat Disord. 2006; 6:2. https://doi.org/10.1186/1472-6815-6-2.

8. Ribeiro KC, Kowalski LP, Latorre MR. Impact of comorbidity, symptoms, and patients' characteristics on the prognosis of oral carcinomas. Arch Otolaryngol Head Neck Surg. 2000; 126:1079-85.

9. Psyrri A, Licitra L, Lacombe D, Schuuring E, Budach W, Ozsahin M, Knecht R, Vermorken JB, Langendijk JA. Strategies to promote translational research within the European Organisation for Research and Treatment of Cancer (EORTC) Head and Neck Cancer Group: a report from the Translational Research Subcommittee. Ann Oncol. 2010; 21:1952-60. https://doi.org/10.1093/annonc/mdq060.

10. Graveland AP, de Maaker M, Braakhuis BJ, de Bree R, Eerenstein SE, Bloemena E, Leemans CR, Brakenhoff RH. Molecular detection of minimal residual cancer in surgical margins of head and neck cancer patients. Cell Oncol. 2009; 31:317-28. https://doi.org/10.3233/CLO-2009-0474.

11. Le Tourneau C, Jung GM, Borel C, Bronner G, Flesch H, Velten M. Prognostic factors of survival in head and neck cancer patients treated with surgery and postoperative radiation therapy. Acta Otolaryngol. 2008; 128:706-12. https://doi.org/10.1080/00016480701675668.

12. Smits RW, Koljenovic S, Hardillo JA, Ten Hove I, Meeuwis CA, Sewnaik A, Dronkers EA, Bakker Schut TC, Langeveld TP, Molenaar J, Hegt VN, Puppels GJ, Baatenburg de Jong RJ. Resection margins in oral cancer surgery: room for improvement. Head Neck. 2016; 38:E2197-203. https://doi. org/10.1002/hed.24075.

13. An Y, Park HS, Kelly JR, Stahl JM, Yarbrough WG, Burtness BA, Contessa JN, Decker RH, Koshy M, Husain 
ZA. The prognostic value of extranodal extension in human papillomavirus-associated oropharyngeal squamous cell carcinoma. Cancer. 2017; 123:2762-72. https://doi. org/10.1002/cncr.30598.

14. Matsumoto F, Mori T, Matsumura S, Matsumoto Y, Fukasawa M, Teshima M, Kobayashi K, Yoshimoto S. Prognostic significance of surgical extranodal extension in head and neck squamous cell carcinoma patients. Jpn J Clin Oncol. 2017; 47:699-704. https://doi.org/10.1093/jjco/ hyx 055 .

15. Amit M, Na'ara S, Leider-Trejo L, Akrish S, Cohen JT, Billan S, Gil Z. Improving the rate of negative margins after surgery for oral cavity squamous cell carcinoma: a prospective randomized controlled study. Head Neck. 2016; 38:E1803-9. https://doi.org/10.1002/hed.24320.

16. Machtay M, Moughan J, Trotti A, Garden AS, Weber RS, Cooper JS, Forastiere A, Ang KK. Factors associated with severe late toxicity after concurrent chemoradiation for locally advanced head and neck cancer: an RTOG analysis. J Clin Oncol. 2008; 26:3582-9. https://doi.org/10.1200/ JCO.2007.14.8841.

17. Keereweer S, Kerrebijn JD, Al-Mamgani A, Sewnaik A, Baatenburg de Jong RJ, van Meerten E. Chemoradiation for advanced hypopharyngeal carcinoma: a retrospective study on efficacy, morbidity and quality of life. Eur Arch Otorhinolaryngol. 2012; 269:939-46. https://doi. org/10.1007/s00405-011-1694-8.

18. Cooper JS, Pajak TF, Forastiere AA, Jacobs J, Campbell BH, Saxman SB, Kish JA, Kim HE, Cmelak AJ, Rotman M, Machtay M, Ensley JF, Chao KS, et al. Postoperative concurrent radiotherapy and chemotherapy for highrisk squamous-cell carcinoma of the head and neck. N Engl J Med. 2004; 350:1937-44. https://doi.org/10.1056/ NEJMoa032646.

19. Hinni ML, Ferlito A, Brandwein-Gensler MS, Takes RP, Silver CE, Westra WH, Seethala RR, Rodrigo JP, Corry J, Bradford CR, Hunt JL, Strojan P, Devaney KO, et al. Surgical margins in head and neck cancer: a contemporary review. Head Neck. 2013; 35:1362-70. https://doi. org/10.1002/hed.23110.

20. Johnson JT, Wagner RL, Myers EN. A long-term assessment of adjuvant chemotherapy on outcome of patients with extracapsular spread of cervical metastases from squamous carcinoma of the head and neck. Cancer. 1996; 77:181-5. https://doi.org/10.1002/(SICI)10970142(19960101)77:1<181::AID-CNCR29>3.0.CO;2-0.

21. Teutsch S, Bas M, Bier H, Knopf A. [Stomal cancer recurrency, a clinic-pathological consideration]. [Article in German]. Laryngorhinootologie. 2016; 96:239-43. https:// doi.org/10.1055/s-00 42-117642.

22. Eloy JA, Vivero RJ, Hoang K, Civantos FJ, Weed DT, Morcos JJ, Casiano RR. Comparison of transnasal endoscopic and open craniofacial resection for malignant tumors of the anterior skull base. Laryngoscope. 2009; 119:834-40. https://doi.org/10.1002/lary.20186.
23. Chauhan P, Byrne H, Taylor E, Sheahan P. Oncological and functional outcomes of transoral surgery for the treatment of oropharyngeal cancer. Ir J Med Sci. 2015; 184:825-30. https://doi.org/10.1007/s11845-014-1183-3.

24. Sessions DG, Spector GJ, Lenox J, Parriott S, Haughey B, Chao C, Marks J, Perez C. Analysis of treatment results for floor-of-mouth cancer. Laryngoscope. 2000; 110:1764-72. https://doi.org/10.1097/00005537-200010000-00038.

25. Affleck DG, Karwande SV, Bull DA, Haller JR, Stringham JC, Davis RK. Functional outcome and survival after pharyngolaryngoesophagectomy for cancer. Am J Surg. 2000; 180:546-50.

26. Eldeeb H, Macmillan C, Elwell C, Hammod A. The effect of the surgical margins on the outcome of patients with head and neck squamous cell carcinoma: single institution experience. Cancer Biol Med. 2012; 9:29-33. https://doi. org/10.3969/j.issn.2095-3941.2012.01.005.

27. Loree TR, Strong EW. Significance of positive margins in oral cavity squamous carcinoma. Am J Surg. 1990; 160:410-4.

28. Bernier J. Head and neck oncology: what the past decade has taught us. Expert Rev Anticancer Ther. 2006; 6:1133-6. https://doi.org/10.1586/14737140.6.9.1133.

29. Bennett SH, Futrell JW, Roth JA, Hoye RC, Ketcham AS. Prognostic significance of histologic host response in cancer of the larynx or hypopharynx. Cancer. 1971; 28:1255-65.

30. Porceddu SV, Campbell B, Rischin D, Corry J, Weih L, Guerrieri M, Grossi M, Peters LJ. Postoperative chemoradiotherapy for high-risk head-and-neck squamous cell carcinoma. Int J Radiat Oncol Biol Phys. 2004; 60:36573. https://doi.org/10.1016/j.ijrobp.2004.03.011.

31. Ferlito A, Rinaldo A, Devaney KO, MacLennan K, Myers JN, Petruzzelli GJ, Shaha AR, Genden EM, Johnson JT, de Carvalho MB, Myers EN. Prognostic significance of microscopic and macroscopic extracapsular spread from metastatic tumor in the cervical lymph nodes. Oral Oncol. 2002; 38:747-51.

32. Bernier J, Cooper JS, Pajak TF, van Glabbeke M, Bourhis J, Forastiere A, Ozsahin EM, Jacobs JR, Jassem J, Ang KK, Lefebvre JL. Defining risk levels in locally advanced head and neck cancers: a comparative analysis of concurrent postoperative radiation plus chemotherapy trials of the EORTC (\#22931) and RTOG (\# 9501). Head Neck. 2005; 27:843-50. https://doi.org/10.1002/hed.20279.

33. Slootweg PJ, Hordijk GJ, Schade Y, van Es RJ, Koole $\mathrm{R}$. Treatment failure and margin status in head and neck cancer. A critical view on the potential value of molecular pathology. Oral Oncol. 2002; 38:500-3.

34. Alicandri-Ciufelli M, Bonali M, Piccinini A, Marra L, Ghidini A, Cunsolo EM, Maiorana A, Presutti L, Conte PF. Surgical margins in head and neck squamous cell carcinoma: what is 'close'? Eur Arch Otorhinolaryngol. 2013; 270:26039. https://doi.org/10.1007/s00405-012-2317-8. 
35. Meier JD, Oliver DA, Varvares MA. Surgical margin determination in head and neck oncology: current clinical practice. The results of an International American Head and Neck Society Member Survey. Head Neck. 2005; 27:952-8. https://doi.org/10.1002/hed.20269.
36. Houssami N, Macaskill P, Marinovich ML, Morrow M. The association of surgical margins and local recurrence in women with early-stage invasive breast cancer treated with breast-conserving therapy: a meta-analysis. Ann Surg Oncol. 2014; 21:717-30. https://doi.org/10.1245/ s10434-014-3480-5. 